\title{
ANALISIS PRODUK PERKEBUNAN RAKYAT UNGGULAN DAN DAMPAKNYA TERHADAP DAYA SERAP TENAGA KERJA UNTUK PENGENTASAN KEMISKINAN DI KABUPATEN BATANGHARI
}

\author{
Sesraria Yuvanda ${ }^{1}$ \\ STIE Muhammadiyah Jambi ${ }^{1}$ \\ sesraria@,gmail.com \\ Ratih Rosita ${ }^{2}$ \\ STIE Muhammadiyah Jambi ${ }^{2}$ \\ ratihrosita11@,gmail.com
}

\begin{abstract}
Ringkasan
Keberhasilan pembangunan ekonomi Kabupaten Batang Hari di bidang pertanian didominasi oleh subsektor perkebunan yang tergambar dari kontribusi subsektor perkebunan terhadap PDRB Kabupaten Batanghar sebesar 30,35\% pada tahun 2014 dan 30,43\% pada tahun 2015. Kontribusi tersebut menduduki urutan pertama dalam distribusi persentase PDRB Kabupaten Batanghari.

Permasalahan dalam penelitian ini adalah Produk perkebunan rakyat manakah yang terpilih menjadi unggulan, Faktor-faktor apakah mempengaruhi perkembangan Produk perkebunan rakyat unggulan, dampak perkembangan Produk perkebunan rakyat unggulan terhadap daya serap tenaga kerja untuk pengentasan kemiskinan, dan bagaimanakah dampak produk perkebunan rakyat unggulan dengan pengentasan kemiskinan di kabupaten Batanghari.

Untuk menjawab tujuan penelitian pertama digunakan model Time Series dan The Indexes of Production Instability. Untuk menjawab tujuan penelitian kedua digunakan model Analisis Regresi berganda. Kemudian untuk menjawab tujuan penelitian ketiga dan keempat digunakan modal analisis regresi sederhan. Untuk mendapatkan data dan informasi yang dibutuhkan, maka digunakan metode penelitian analisis data sekunder dan metode penelitian observasi.

Hasil penelitian ini adalah Produk Perkebunan Rakyat unggulan yang terpilih adalah Karet, Faktor yang paling signifikan yang mempengaruhi perkembangan Produk Perkebunan rakyat unggulan adalah harga produk perkebunan rakyat pesaing dan investasi pada sektor perkebunan. Pengembangan produk perkebunan rakyat unggulan tidak berpengaruh signifikan terhadap daya serap tenaga kerja dan pengentasan kemiskinan, Pengembangan produk perkebunan rakyat unggulan tidak berpengarauh signifikan antara dalam pengentasan kemiskinan.
\end{abstract}

Kata kunci : Produk perkebunan, Unggulan, Tenaga Kerja, Kemiskinan

\section{PENDAHULUAN}

Keberhasilan pembangunan ekonomi Kabupaten Batanghari di bidang pertanian didominasi oleh subsektor perkebunan. Hal ini tergambar dari kontribusi subsektor perkebunan terhadap PDRB Kabupaten Batanghari. Dalam selang waktu 2 tahun terakhir kontribusi sub sektor perkebunan terhadap PDRB besar yaitu sebesar 30,35\% pada tahun 2014 dan sebesar $30,43 \%$ pada tahun 2015. Kontribusi tersebut menduduki urutan pertama dalam distribusi persentase PDRB Kabupaten Batanghari. 
Kondisi tersebut mempunyai konsekuensi bahwa pembangunan perkebunan harus menjadi perhatian besar agar kontribusinya dapat ditingkatkan. Oleh karena itu, dalam pembangunan sub sektor perkebunan perlu dipilih dan ditetapkan produk unggulannya. Didapati beberapa produk perkebunan yang telah dikembangkan di Kabupaten Batanghari seperti karet, sawit, kopi, kelapa. produk tersebut perlu dipilih dan ditetapkan agar didapati produk perkebunan rakyat unggulan yang menjadi fokus perhatian dalam pembangunan perkebunan di masa datang.

Dalam konteks ekonomi makro, produk perkebunan rakyat unggulan terpilih dalam perkembanganya akan dipengaruhi oleh faktor eksternal seperti faktor harga produk unggulan, harga produk pesaing, suku bunga, investasi pada sub sektor perkebunan. Faktor tersebut harus menjadi perhatian dalam merumuskan kebijakan karena akan mempengaruhi besaran transaksi atas perkembangan produk perkebunan rakyat unggulan yang terpilih.

Keberhasilan pengembangan produk perkebunan yang terpilih melalui kebijakan yang tepat akan memberi pengaruh terhadap ekonomi suatu daerah baik ditingkat petani maupun ditingkat regional. Pengembangan produk perkebunan rakyat unggulan bagi daerah Kabupaten Batanghari yang perekonomiannya didominasi oleh sub sector perkebunan akan berpengaruh terhadap perkembangan ekonomi makro.

Oleh karena, kegiatan perkebunan bersifat padat karya maka pengembangan produk perkebunan rakyat unggulan juga akan berpengaruh terhadap peningkatan daya serap tenaga kerja pada subsektor perkebunan. Peningkatan daya serap tenaga kerja sebagai akibat perkembangan produk perkebunan rakyat unggulan akan terlihat pada jumlah tenaga kerja yang bekerja pada perkebunan yang menghasilkan produk perkebunan tersebut.

Penyerapan tenaga kerja pada perkebunan rakyat tiap tahunnya mengalami fluktuasi. Pada tahun 2013, daya serap sub sektor perkebunan sebanyak 68.355 orang. Naik menjadi 71.936 pada tahun 2014. Kemudian pada tahun 2015 mengalami penurunan hingga menjadi 66.883 orang. Namun, daya serap tersebut mempunyai peran berarti terhadap total angkatan kerja di Kabupaten Batanghari. Hal ini terlihat dimana pada tahun 2013 sebesar 62,92\% tenaga kerja diserap oleh perkebunan rakyat, lalu meningkat pada tahun 2014 sebesar 65,16\%. Namun pada tahun 2015 mengalami penurunan menjadi 58,38\% dari angkatan kerja.

Tertarik untuk menganalisis lebih lanjut tentang pemilihan dan penetapan produk perkebunan rakyat unggulan beserta faktor ekonomi makro yang mempengaruhi perkembangannya dan menganalisis pula pengaruh perkembangan produk tersebut terhadap 
perkembangan ekonomi daerah perekonomian dan daya serap tenaga kerja maka diperlukan suatu penelitian yang komperensif. Penelitian tersebut berjudul " Analisis produk Perkebunan rakyat unggulan Dan Dampaknya Terhadap Daya Serap Tenaga Kerja Untuk Pengetasan Kemiskinan Di Kabupaten Batanghari”.

\section{Perumusan Masalah}

Mayoritas penduduk miskin dikabupaten Batanghari berada pada sektor pertanian khususnya perkebunan rakyat. Disamping itu perkebunan rakyat memiliki daya serap tertinggi. Untuk mengentaskan kemiskinan dari petani yang bekerja pada pekerbunan rakyat perlu dilakukan pengidentifikasi dan penetapan produk-produk perkebunan rakyat yang menjadi unggulan agar petani selaku tanaga kerja pada pekerbunan rakyat dapat ditingkatkan kesejahteraanya pada produk unggulan dari perkebunan rakyat. Ini berarti pendekatan dalam pengentasan kemiskinan berbasis pada peningkatan produksi yang berorientasi pasar dan dapat meningkatkan nilai tambah bagi tenaga kerja sehingga petani selaku tenaga kerja dapat keluar dari kemiskinan.

Adapun yang menjadi perumusan masalah dari penelitian ini adalah :

1. Produk perkebunan rakyat manakah yang terpilih menjadi produk perkebunan rakyat unggulan di Kabupaten Batanghari

2. Faktor-faktor apakah mempengaruhi perkembangan produk perkebunan rakyat unggulan di Kabupaten Batanghari

3. Bagaimanakah dampak perkembangan produk perkebunan rakyat unggulan terhadap daya serap tenaga kerja untuk pengentasan kemiskinan di Kabupaten Batanghari

4. Bagaimanakan dampak produk perkebunan rakyat unggulan dengan pengentasan kemiskinan di kabupaten Batanghari

Asumsi yang digunakan dalam penelitian ini adalah pengembangan produk-produk unggulan dari perkebunan rakyat yang dapat memiliki daya serap tenaga kerja yang tinggi akan memberikan kontribusi terhadap pengentasan kemiskinan.

Penelitian ini dirancang untuk lingkup produk yang dihasilkan perkebunan rakyat yang ada dikabupaten Batanghari. Sedangkan lingkup yang terkait dengan tenaga kerja adalah tenaga kerja yang terlibat langsung dalam proses produksi untuk menghasilkan produk perkebunan rakyat. Selanjutnya tenaga kerja yang terlibat tersebut akan dihubungkan dengan tingkat kemiskinan petani yang bekerja pada perkebunan rakyat selaku tenaga kerja. 


\section{METODOLOGI}

Dalam penelitian ini untuk menjawab tujuan permasalahan yang telah dikemukaan maka digunakan 4 model sebagai berikut :

\section{Model Analisis Pertama}

Untuk menjawab tujuan penelitian yang pertama yaitu menentukan produk Perkebunan rakyat unggulan yang memenuhi kriteria yang telah ditetapkan, maka digunakan dua model analisis berikut. Kedua model tersebut dilakukan secara bertahap yaitu :

Tahap 1. Model Analisis Time Series,

Untuk memenuhi kriteria produk perkebunan rakyat unggulan harus menunjukan arah trend positif dari perkembangannya. Untuk mengetahui arah trend dari perkembangannya maka digunakan model analisis Time Series dan dengan formulasi sebagai berikut (Gujarati, 1995) :

$$
\mathbf{P K P}_{\mathbf{i}}=\mathbf{a}+\mathbf{b t}+\mathbf{e}_{\mathbf{1}}
$$

dimana :

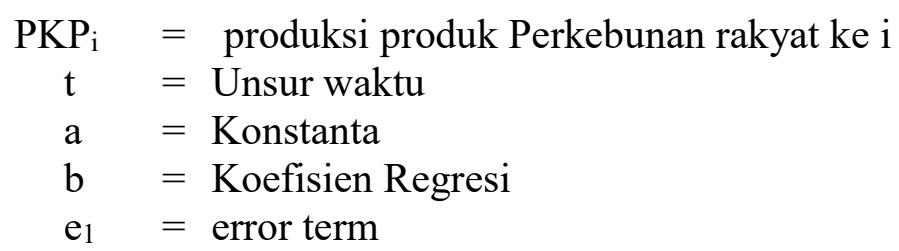

Dari Model Analisis Time Series akan diperoleh koefisien regresi (b) yang menunjukkan arah trend (positif atau negatif) masing-masing produk Perkebunan rakyat. produk perkebunan rakyat unggulan yang terpilih adalah produk perkebunan rakyat yang memiliki arah trend positif.

Tahap 2. Model Analisis The Indexes of Production Instability

Selain melihat trend apakah produk perkebunan rakyat unggulan maka diapat dilihat dari kestabilan produksi produk perkebunan rakyat tersebut stabil. Untuk itu maka model yang digunakan selanjutnya adalah Model Analisis The Indexes of Production Instability yang merupakan modifikasi dari model The Indexes of Export Instability yang dikembangkan Yotopoulos dan Nugent (1976). Adapun formulasinya adalah:

$$
I_{i n s-p r o}=\left[\frac{1}{\ln \overline{P R O}} \sqrt{\frac{\sum_{t=1}^{n}\left(\ln \operatorname{Pr} o_{t}-\ln P R \hat{O}\right)^{2}}{N}}\right] \times 100
$$

dimana :

$$
\begin{array}{ll}
\mathrm{I}_{\text {ins-pro }} & =\text { Indeks Kestabilitasan Produksi Perkebunan Rakyat } \\
N & =\text { Jumlah tahun observasi } \\
\mathrm{t} & =1,2, \ldots \ldots \ldots \ldots \ldots \ldots ., \mathrm{N}
\end{array}
$$




$$
\begin{array}{ll}
\text { PRO } & =\text { Tingkat produksi produk produk perkebunan rakyat ke } \mathrm{i} \\
\stackrel{\mathrm{PRO}}{\wedge} & =\text { Menunjukkan rata-rata PRO } \\
\stackrel{\mathrm{PRO}}{\mathrm{PRO}} & =\text { Nilai estimasi dari } \ln \mathrm{PRO}_{\mathrm{t}}=\mathrm{a}+\mathrm{bt}+\mathrm{U}_{\mathrm{t}}
\end{array}
$$

Bila indeks yang dihasilkan semakin mendekati nilai 0, berarti tingkat produksi dari produk perkebunan rakyat unggulan yang dianalisis semakin stabil dan sebaliknya. Ini berarti produk perkebunan rakyat unggulan yang terpilih adalah produk perkebunan yang memiliki indeks kestabilitasan produksi yang terkecil atau semakin mendekati nol.

Model Analisis Kedua

Untuk menjawab tujuah kedua dalam penelitian ini yaitu untuk mengetahui faktorfaktor yang mempengaruhi perkembangan produk perkebunan rakyat unggulan, maka digunakan Model Analisis Regresi Berganda. Adapun formulasinya adalah sebagai berikut : dimana :

$$
\mathbf{P K U}_{t}=b_{0}+b_{1} H_{K A}+b_{2} H_{K} P_{t}+b_{3} J P P P_{t}+b_{4} I S P P_{t}+e_{2}
$$

$P K U_{t} \quad$ : Produksi produk perkebunan rakyat unggulan

HKA : Harga produk perkebunan rakyat unggulan

HKP : Harga produk perkebunan rakyat pesaing

JPP : Jalan Produksi Perkebunan rakyat

ISP : Investasi pada subsektor perkebunan rakyat

$\mathrm{e}_{2} \quad:$ error term

B : koefisien regresi

Model Analisis Ketiga

Untuk menjawab tujuan ketiga dalam penelitian ini yaitu untuk mengetahui pengaruh Perkembangan produk Perkebunan rakyat unggulan terhadap peningkatan daya serap tenaga kerja untuk pengentasa kemiskinan maka digunakan model analisis Regresi Sederhana. Adapun formulasinya adalah sebagai berikut :

$$
\text { PTK }_{t}=d_{0}+d_{1} P_{K U_{t}}+\mathbf{e}_{4}
$$

\section{Dimana :}

PTK : Penyerapan Tenaga Kerja untuk pengentasan kemiskinan

$P K U_{t} \quad$ : Produksi produk perkebunan rakyat unggulan

$\mathrm{E}_{4} \quad: \quad$ error term

d : koefisien regresi

Model Analisis Keempat

Untuk menjawab tujuan keempat dalam penelitian ini yaitu untuk melihat dampak produk perkebunan rakyat unggulan terhadap pengentasan kemiskinan di Kabupaten Batanghari maka digunakan model analisis regresi sederhana. Adapun formulasinya adalah sebagai berikut :

$$
\mathbf{P K M}_{t}=\mathbf{f}_{0}+\mathbf{f}_{1} \mathrm{PKU}_{\mathrm{t}}+\mathbf{e}_{5}
$$


Dimana :

PKM : Penduduk Miskin

$P K U_{t} \quad$ : Produksi produk perkebunan rakyat unggulan

$\mathrm{e}_{5} \quad:$ error term

$\mathrm{F} \quad$ : koefisien regresi

\section{HASIL PENELITIAN}

\section{A. Analisis Produk Perkebunan Rakyat Unggulan}

Untuk menentukan produk perkebunan rakyat unggulan yang memenuhi kriteria maka digunakan 2 model analisis yaitu model analisis time series, dan model analisis indexes of production instability. Penggunaan kedua model analisis tersebut dilakukan secara bertahap.

\section{Tahap I. Analisis Time series}

Dalam menggunakan model analisis time series maka penentuan produk perkebunan rakyat unggulan ditentukan dengan melihat arah trend positif dari produksi perkebunan rakyat tersebut. Hasil dari penggunaan model tersebut memperlihatkan bahwa dari 5 perkebunan rakyat dengan komoditi karet, sawit, kelapa dalam, kelapa hibrida dan kopi terpilih menjadi produk perkebunan rakyat unggulan adalah karet dan sawit. Hal ini disebabkan karena produk tersebut mempunyai koefiesien regresinya menunjukan arah trend yang positip. Seperti yang diperlihatkan oleh tabel berikut ini.

Tabel 1. Hasil Analisis Model Time Series Produk Perkebunan Rakyat yang ada dikabupaten Batang Hari

\begin{tabular}{|c|c|c|c|}
\hline No & $\begin{array}{l}\text { Komoditas } \\
\text { perkebunan }\end{array}$ & Persamaan regresi time series & Arah trend \\
\hline 1 & Karet & $Y=(-5947728,800)+2989,073 X+e$ & Positip \\
\hline 2 & Kelapa Dalam & $\mathrm{Y}=71333,873-35,236 \mathrm{X}+\mathrm{e}$ & Negatif \\
\hline 3 & Kelapa Hibrida & $Y=19554,864-9,682 X+e$ & Negatif \\
\hline 4 & Sawit & $Y=(-18239740,545)+9176,182 X+e$ & Positip \\
\hline 5 & Kopi & $\mathrm{Y}=20585,936-10,209 \mathrm{X}+\mathrm{e}$ & Negatif \\
\hline
\end{tabular}

Tahap II. Analisis Indexes of production instability

Untuk melihat apakah produksi perkebunan rakyat unggulan stabil maka digunakan model analisis Indexes of production instability. Hasil perhitungan Indexes of production instability terhadap produk perkebunan rakyat yang ada dikabupaten Batang Hari dalam rangka menentukan produk perkebunan rakyat unggulan yang terpilih diperlihatkan pada tabel berikut ini.

Tabel 2. Perhitungan Indexes of production instability terhadap Produk Perkebunan Rakyat

\begin{tabular}{|l|l|c|}
\hline No & Produk perkebunan rakyat & Indexes of production instability \\
\hline $\mathbf{1}$ & Karet & $\mathbf{1 , 5 6 9 4 3 3 2 8}$ \\
\hline 2 & Sawit & 10,34639203 \\
\hline
\end{tabular}


Bila indeks yang dihasilkan dari perhitungan tabel diatas mendekati nilai nol berarti tingkat produksi produk perkebunan rakyat tersebut semakin stabil dan layak untuk terpilih menjadi produk perkebunan rakyat unggulan. Mengacu kepada ketentuan tersebut maka produk perkebunan rakyat unggulan yang terpilih adalah karet. Hal ini diperlihatkan pada indexes of production instability pada tabel di atas untuk karet adalah 1,56943328. Indeks tersebut angkanya paling kecil dan mendekati nol dibandingkan dengan perkebunan sawit.

Ini berarti karet terpilih menjadi produk perkebunan rakyat unggulan di Kabupaten Batang Hari berdasarkan analisis time series dan analisis indexes of production instability.

Mengacu kepada kedua model analisis diatas (time series dan indexes of production instability) maka dapat disimpulkan bahwa karet merupakan produk perkebunan rakyat unggulan di kabupatenn Batang Hari. Dengan demikian pengembangan perkebunan rakyaat unggulan harus mengacu kepada produk yang terpilih yaitu karet.

\section{B. Analisis Faktor-faktor Yang Mempengaruhi Perkembangan Produk Perkebunan Rakyat Unggulan}

Untuk menganalisis faktor-faktor ekonomi yang mempengaruhi perkembangan produk perkebunan rakyat unggulan maka digunakan model analisis regresi berganda. Untuk mempermudah perhitungan maka digunakan program software komputer SPSS 2.3 guna mendapatkan persamaan regresi berganda yang diperoleh dari penggunaan software tersebut adalah :

Tabel. 3 Koefisien Regresi Faktor-faktor Yang Mempengaruhi Perkembangan Produk Perkebunan Produk Unggulan

\begin{tabular}{|c|c|c|c|c|c|c|}
\hline \multirow{2}{*}{\multicolumn{2}{|c|}{ Model }} & \multicolumn{2}{|c|}{ Unstandardized Coefficients } & \multirow{2}{*}{$\begin{array}{c}\text { Standardized } \\
\text { Coefficients } \\
\text { Beta }\end{array}$} & \multirow[b]{2}{*}{$t$} & \multirow[b]{2}{*}{ Sig. } \\
\hline & & $\mathrm{B}$ & Std. Error & & & \\
\hline & (Constant) & 4,119 & 2,412 & & 1,708 &, 139 \\
\hline & LOGHKA &,- 164 & ,135 &,- 361 & $-1,213$ & ,271 \\
\hline & LOGHKP &, 437 & ,168 & ,723 & 2,607 & ,040 \\
\hline & LOGJPP &,- 100 & ,408 &,- 043 &,- 245 & ,815 \\
\hline & LOGISP & ,092 & ,031 & ,626 & 3,021 & ,023 \\
\hline
\end{tabular}

a. Dependent Variable: LOGKARET

Dari tabel annova diatas didapat model persamaan regresinya sebagai berikut $\mathrm{PKU}_{t}=4,119-0,164 \mathrm{HKA}+0,437 \mathrm{HKP}-0,100 J P P+0,092$ ISP $+\mathrm{e}$

Secara keseluruhan variable harga produk perkebunan rakyat unggulan (karet), harga produk perkebunan rakyat pesaing, jalan produksi perkebunan dan investasi pada sektor perkebunan mempunyai pengaruh signifikan terhadap produksi perkebunan rakyat unggulan (karet) pada F hitung 9,686 yang signifikasn pada alpha $=0,009$. Sedangkan 
secara parsial hanya variable harga produk perkebunan rakyat pesaing dan investasi yang berpengaruh signifikan terhadap produksi perkebunan rakyat unggulan (karet).

Untuk variable harga produk perkebunan rakyat unggulan dan jalan produksi tidak punya pengaruh yang signifikan terhadap produksi perkebunan rakyat unggulan. Hal ini dikarenakan harga produk perkebunan rakyat unggulan (karet) lebih banyak ditentukan oleh system kopuik dimana kenaikan harga tidak memberikan pengaruh terhadap produksi karet. Sedangkan jalan produksi pertanian tidak juga berpengaruh terhadap produksi perekebunan rakyat unggulan karena jalan produksi yang dibangun tidak menjangkau sentra-sentra produksi karet khususnya karet rakyat. Hal ini dapat dipahami karena sebaran sentra yang terlalu jauh sedangkan jalan produksi terbatas dan tidak mampu menjangkau sentra tersebut.

\section{Analisis Dampak Produk Perkebunan Rakyat Unggulan Terhadap Daya Serap} Tenaga Kerja untuk Pengentasan Kemiskinan

Untuk menganalisis dampak Produk Perkebunan Rakyat Uanggulan terhadap daya serap tenaga kerja untuk pengentasan kemiskinan maka digunakan model regresi sederhana dan data dioleh dengan menggunakan program SPSS 2.3 yang mana koefisien masing-masing variable dapat dilihat pada tabel berikut ini.

Tabel 4. Koefisien Regresi Dampak Produk Perkebunan Rakyat Unggulan Terhadap Daya Serap Tenaga Kerja Untuk Pengentasan Kemiskinan

\section{Coefficients $^{\text {a }}$}

\begin{tabular}{|c|c|c|c|c|c|}
\hline \multirow[b]{2}{*}{ Model } & \multicolumn{2}{|c|}{$\begin{array}{c}\text { Unstandardized } \\
\text { Coefficients }\end{array}$} & $\begin{array}{l}\text { Standardized } \\
\text { Coefficients }\end{array}$ & \multirow[b]{2}{*}{$\mathrm{T}$} & \multirow[b]{2}{*}{ Sig. } \\
\hline & $\mathrm{B}$ & Std. Error & Beta & & \\
\hline $1 \quad$ (Constant) & 59817,273 & 15999,539 & & 3,739 &, 005 \\
\hline $\begin{array}{l}\text { PROD. } \\
\text { KARET }\end{array}$ & , 155 &, 250 & ,203 & ,623 & ,549 \\
\hline
\end{tabular}

a. Dependent Variable: PENYERAPAN TK

Dari tabel diatas didapat model persamaan regresi dengan model sebagai berikut

$$
\mathbf{P T K}=59817,273+\mathbf{0}, 155 \mathrm{PKU}+\mathbf{e}
$$

Berdasarkan hasil data olahan, variable produk perkebunan rakyat unggulan untuk daya serap tenaga kerja tidak berpengaruh signifikan terhadap daya serap tenaga kerja untuk pengentasan kemiskinan. Tidak signifikannya variable produk perkebunan rakyat unggulan (karet) terhadap daya serap tenaga kerja untuk pengentasan kemiskinan dikarenakan kurangnya 
minat angkatan kerja untuk bekerja pada perkebunan karet rakyat. Angkatan kerja lebih tertarik bekerja pada sektor perdagangan dan sector jasa di ibukota Provinsi Jambi. Hal ini dikarenakan jarak Ibukota Provinsi dengan kabupaten Batang Hari yang tidak terlalu jauh. Disamping itu upah tenaga kerja yang bekerja pada perkebunan karet rakyat lebih rendah dari pada upah disektor perdagangan dan jasa.

\section{Analisis Dampak Produk Perkebunan Rakyat Unggulan terhadap Kemiskinan}

Untuk melihat dampak produk perkebunan rakyat unggulan terhadap kemiskinan maka digunakan model analisis regresi sederhana. Dengan bantuan program SPSS 2.3 maka didapat tabel coefficients masing-masing variable yang dapat dilihat berikut ini :

Tabel 5. Koefisien regresi dampak Produk Perkebunan Rakyat Unggulan terhadap kemiskinan

\begin{tabular}{|c|c|c|c|c|c|c|}
\hline \multicolumn{7}{|c|}{ Coefficients $^{a}$} \\
\hline \multirow{2}{*}{\multicolumn{2}{|c|}{ Model }} & \multicolumn{2}{|c|}{ Unstandardized Coefficients } & $\begin{array}{c}\text { Standardized } \\
\text { Coefficients }\end{array}$ & \multirow[b]{2}{*}{$\mathrm{t}$} & \multirow[b]{2}{*}{ Sig. } \\
\hline & & $\mathrm{B}$ & Std. Error & Beta & & \\
\hline \multirow[t]{2}{*}{1} & (Constant) & 38036,898 & 7825,715 & & 4,861 & ,001 \\
\hline & PROD. KARET &,- 171 & ,122 &,- 422 & $-1,398$ & , 196 \\
\hline
\end{tabular}

Dari tabel diatas dapat dibuat persamaan regresi berikut ini :

PKM = 38036,898 - 0,171 PKU + e

Hasil diatas memperlihatkan bahwa produk perkebunan rakyat tidak berpengaruh signifikan terhadap kemiskinan. Hal ini disebabkan Petani karet atau buruh karet khususnya perkebunan karet rakyat masih terlibat dalam sistem kapuik. Sistem kapuik tersebut menjadikan petani atau buruh karet dalam mekanisme ijon dimana pedagang karet membeli harga karet dibawah harga pasar dengan lebih dulu membiayai atau memasok kebutuhan hidup petani atau buruh karet sehingga petani atau buruh karet terlibat dalam hutang piutang dengan pedagang karet tanpa melalui sistem pasar lelang

\section{KESIMPULAN}

Berdasarkan hasil penelitian dan pembahasan maka dapat ditarik butir simpulan sebagai berikut :

1. Produk Perkebunan Rakyat unggulan yang terpilih adalah Karet

2. Faktor yang paling signifikan yang mempengaruhi perkembangan Produk Perkebunan rakyat unggulan adalah harga produk perkebunan rakyat pesaing dan investasi pada sektor perkebunan 
3. Pengembangan produk perkebunan rakyat unggulan tidak berpengaruh signifikan terhadap daya serap tenaga kerja dan pengentasan kemiskinan

4. Pengembangan produk perkebunan rakyat unggulan tidak berpengarauh signifikan antara dalam pengentasan kemiskinan

\section{DAFTAR PUSTAKA}

Aris, Ahmad. 2011. Dampak Pengembangan Perkebunan Kelapa Rakyat Terhadap Kemiskinan dan Perekonomian Kabupaten Indragiri Hilir. IPB: Bogor.

Arsyad, L. 2004. Ekonomi Pembangunan, Edisi 3 Bagian Penerbitan STIE YKPN. Yogyakarta.

Elfindri dan Bachtiar, 2004. Ekonomi Ketenagakerjaan. Andalas University Press.

Gujarati, D.1995. Econometrics, McGraw Hill Inc, New York.

Hidayah, Ismaul. 2007. Analisis Prioritas Komoditas Unggulan Perkebunan Kabupaten Buru, AGRIKA Volume 4, Nomor 1, Mei 2010. BPTP Maluku.

Intriligator, M.D, 1980. Econometric Models, Tekhniques, and applications. Prentice Hall Of India. New Delhi.

Irmanelly, I., \& Soleh, A. (2013). Analisis Sektor Unggulan dan Hubungannya dengan

Ketenagakerjaan dan Kemiskinan di Provinsi Jambi. Jurnal Development, 1(1), 15-43.

Marsono, Y, 2004. Pengembangan Strategi produk Unggulan di Kabupaten Batanghari. Bappeda Kabupaten Batanghari-Fakultas Teknologi Pertanian Universitas Gadjah Mada Yogyakarta. Jambi

Simanjuntak, P., 1985. Ekonomi Sumber daya manusia. PAU UI. Jakarta.

Soleh, A. (2018). Analisis dan Strategi Pengentasan Kemiskinan Di Provinsi Jambi. EKSIS: Jurnal Ilmiah Ekonomi dan Bisnis, 9(1), 79-90.

Soeroto, 1986. Kependudukan dan tenaga kerja. PAU-UI. Jakarta

Suryana, H. 2000. Ekonomi sumber daya manusia. Penerbit Salemba empat. Jakarta.

Todaro, M.1983. Economic Development, Sixth edition, Long Man, London and New York.

Wahid, I, 2000. Analisis produk Unggulan Provinsi Yogyakarta. Biro Perekonomian DIY dan LPM UGM.

Wardis, Girsang. 2009. Strategi Pengentasan Kemiskinan di Pulau Kecil di Provinsi Maluku. Jurnal Agrikultura 20 (03): 176-184.

Wulandari, Siri Abir dan Nida Kenala. 2015. Kajian Komoditas Unggulan Subsektor Perkebunan di Provinsi Jambi. Jurnal Ilmiah Universitas Batanghari Jambi, Volume 16, Nomor 1 Tahun 2016. 
Yanti, Rina Trisna. 2012. Pengembangan Komoditas Potensial dan Peranannya Terhadap Perluasan Kesempatan Kerja dan Penanggulangan Kemiskinan di Kabupaten Seluma. Ekombis Review, Universitas Dehasen: Bengkulu.

Yotopoulus, P dan Nuget, J.1976. Economic of Development Emprical Investigations, Harper Internasional, New York. Universitas Pattimura, Ambon. 